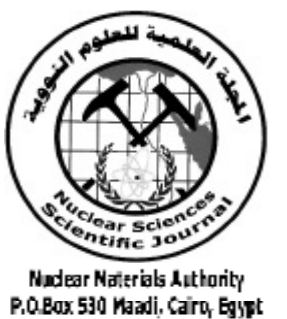

ISSN 2314-5609

Nuclear Sciences Scientific Journal

$5,147-159$

2016

http://www.ssnma.com

\title{
PRELIMINARY RECORD OF URANIUM BEARING SURFICIAL PLAYA DEPOSITS, SOUTHEAST NUSAB EL BALGUM AREA, SOUTH WESTERN DESERT, EGYPT
}

\author{
HASSAN M. ASSRAN \\ Nuclear Materials Authority, P.O.Box: 530 El Maadi, Cairo, Egypt
}

\begin{abstract}
This significant is new record of uranium-surficial playa-lake type in silicrete, calcrete and ferricrete deposits of southeast Nusab El Balgum area. It offers a type model and exploration criterion for surficial uranium occurrences in other similar areas in the southern part of the Western Desert. The physiographic, climate conditions and geological setting of south Western Desert provide an excellent exploration target region for surficial uranium deposits.

Chemical assay of eleven surficial uranium deposit samples recorded in the calcretes have 190 to 130 total $\mathrm{U}$ in ppm averaging $160 \mathrm{ppm}$, in the ferricretes 142 to $106 \mathrm{ppm}$ averaging $122 \mathrm{ppm}$ and in the silicretes 100 to $74 \mathrm{ppm}$ averaging $87 \mathrm{ppm}$, wherever the calcretes cover the largest surface area in the studied area. Carnotite $\left[\mathrm{K}_{2}\left(\mathrm{UO}_{2}\right)_{2}\left(\mathrm{VO}_{4}\right)_{2} .3 \mathrm{H}_{2} \mathrm{O}\right]$ is the main secondary uranium mineral in such surficial deposits.
\end{abstract}

\section{INTRODUCTION}

The studied area is located at south Western Desert of Egypt (Fig. 1), between Lat. $23^{\circ} 00^{\prime}-23^{\circ} 24^{\prime} \mathrm{N}$ and Long. $29^{\circ} 00^{\prime}-29^{\circ} 40^{\prime}$ E (Fig. 2).

The study area can be reached through asphaltic road from Aswan-Tushki $(220 \mathrm{Km})$ Darb El Arbain $(226 \mathrm{Km})$-El Kharga road north $(90 \mathrm{Km})$-Bir Abu El Hussien-Bir Tarafawi west $(80 \mathrm{Km})$ along old asphaltic road, or through El Dakhla-Sharq El Uweinat village and to the east $(50 \mathrm{Km})$ through Bir TarafawiBir Abu El Hussien old asphaltic road. Three old dry wells filled up by windblown sands are located outside of the mapped area. Their limits are Bir Safsaf in the south, Bir Tarafawi in the west and Bir Abu El Hussien in the east of study area confirming a shallow depth of the ground water in the studied area.

The surficial playa deposits of the lake type environment given in the Britannica on- line encyclopedia (2012) represent flat-bottom depressions deposits with slopes less than 0.2 meter per kilometer found in interior desert basins within arid and semi-arid regions with interior drainage to a zone, which periodically covered by water that slowly filtrated into the ground water system or evaporated the depositing salt, sand and mud along the bottom and around the edges of the depressions. Uranium is recorded in the surficial playa deposits of Western Australia.

Uraniferous-surficial playa deposits may be broadly defined as uraniferous sediments or soils, usually of Tertiary to Recent age, that have not been subjected to deep burial and may or may not have been cemented to limited degree. It is recognized that, there are many cementing minerals. These include (in approximate order of importance), calcite, gypsum, dolomite, ferric oxides, strontianite and halite (Pagel, 1984). Generally, uraniferous surficial deposits are mainly represented 
by calcretes, ferricretes, silicretes and playa evaporates (Butt, 1988). Calcrete deposits of calcium and magnesium carbonates as cementing material are common. The ferricrete of ferric oxide as cementing material, silicrete of silica cementing material and playa evaporates (Butt, 1988). The calcrete bodies are interbedded with Tertiary sand and clay, being usually cemented by calcium and magnesium carbonates. Uraniferous calcrete deposits form in regions, where uranium-rich granites were deeply weathered in a semi-arid to arid climate. Surficial uranium deposits also occur in peat bogs, karst caverns and soils (McKay and Miezitis, 2001).

In Western Australia, the uranium-calcrete deposits occur in valley-fill sediments along Tertiary drainage channels (e.g. Yeelirrie) and in playa lake sediments (e.g. Lake Maitland). These deposits overlie Archaean granite and greenstone basement of the northern portion of the Yilgarn Craton. The uranium mineralization is carnotite (hydrated potassium uranium vanadium oxide). The Yeelirrie deposit is by far the world's largest U-surficial deposit. It contains $52500 \mathrm{t} \mathrm{U}_{3} \mathrm{O}_{8}$ in resources averaging $0.15 \% \mathrm{U}_{3} \mathrm{O}_{8}$. Other significant deposits in Western Australia include Lake Way, Centipede and Thatcher Soak. Calcrete deposits represent approximately $5 \%$ of Australia's total reserves and resources of uranium (IAEA, 1990).

Carnotite mineral $\left[\begin{array}{lll}\mathrm{K}_{2} & \left(\mathrm{UO}_{2}\right)_{2} & \left(\mathrm{VO}_{4}\right)_{2}\end{array}\right.$ $\left..3 \mathrm{H}_{2} \mathrm{O}\right]$ represents the main uranium mineral in playa or surficial deposits. It can be distributed in one or more of the following ways (Pagel, 1984):

-Isolated discontinuous sheets or lenses.

-Fine-grained disseminated material in the more calcareous clays as fine crystallites.

-In fissures in calcite and dolomite.

-Coating along cracks, bedding and slippage on clays.

-Patches on clays.

-In interstices between sand grains.
-Narrow steeply dipping stringers in sands and calcareous material.

-Films on the walls of voids as euhedral to anhedral crystals.

Granites and related igneous rocks and, to a lesser extent, high-grade metamorphic rocks that were partially melted are the major source terranes of uranium in arid land and wetland uranium-surficial deposits (Carlisle 1984; Culbert et al., 1984 and Otton, 1984). The source of vanadium, an important constituent of most arid land uranium-surficial deposits, is a point of controversy. Workers in Australia have proposed two sources: the mafic minerals associated with granites (specifically hornblende, biotite and the iron-and titanium-oxide minerals), or the metavolcanics of the greenstone belts. Further work seems essential, and some of that work ought to focus on the provenance of the fluorine, zinc and strontium in groundwater as the Yeelirrie deposits inWest Australia (Briot and Fuchs, 1984).

Although most large uranium-surficial deposits are near source rocks that are enriched in uranium (significantly greater than 5ppm), many deposits have formed in terranes where granites and other rocks appear to have average (1 to 5ppm) uranium contents. Additional favorable circumstances, such as extensive fracturing or an unusually labile mineralogical residence for the uranium, may allow sufficient uranium in solution to enter the surficial environment and to be deposited (Culbert et al., 1984).

Otton (1984) concluded that, the transport of uranium required oxidizing conditions in the source and in the environments between the source and the host. Transport is less sensitive to the presence of complexes because, although complexes increase the solubility of uranium, a wide variety of complexes occur in almost all natural water. For virtually all uranium-surficial deposits, uranium is liberated from source rocks by leaching and is transported by oxidizing surface waters or 
shallow groundwater. In arid lands, uranium is generally leached from source rocks by slightly alkaline, oxidizing water and carried as uranyl carbonate or bicarbonate complexes. Oxidizing conditions persist and the alkalinity and salinity of the water tend to increase down flow, keeping the uranyl ions in solution until fixation mechanisms intervene. In tropical and wetland environments, transport distances are generally short (a meter to a few kilometers), whereas in arid lands, transport distances may be long (several tens of kilometers, as the present studied Nusab El Balgum area reaches about $35 \mathrm{~km}$ southeast from uranium source rocks).

The processes involved in the fixation of uranium in surficial deposit environments include one or more of the following states (Boyle, 1984):

1- Dissociation of soluble complexes for example, uranyl carbonate species through loss of $\mathrm{CO}_{2}$ to the atmosphere or precipitation of a carbonate mineral.

2- Evaporative concentration of solute species in near-surface groundwater.

3- Change in valence state of vanadium or uranium which decreases the solubility of the ore mineral. For example, carnotite may form, in part, by the oxidation of $\mathrm{V}^{4+}$ to $\mathrm{V}^{5+}$ where sufficient uranium $\left(\mathrm{U}^{6+}\right)$ is available.

4- Mixing of water creating local super saturation with respect to uranium minerals.

5- Sorption by organic matter followed by reduction of the uranium by reduced sulfur species or organic matter.

6- Sorption by silica, iron hydroxides or oxyhydroxides and clay.

Uranium forms in arid lands individual large deposits enough to support substantial mining and milling operations. These deposits have relatively low mining costs because they are generally near-surface ( 2 to $11 \mathrm{~m}$ ) and can be mined by shallow open-pit techniques (Otton,1984). Extraction costs may be high, because the abundant carbonates and high calcium-magnesium ratio of the carbonates in the ore require alkaline leach techniques rather than acid-based techniques. Abundant clay and fine quartz in the ore tend to form suspensions in the pulp, from which the leaching is difficult to separate (Simonsen et al., 1980).

The surface layer gravel and alluvium is the least radioactive due to the supply of detrital material from non-mineralized sources, yet the layers just below may have concentrations of radioactive elements several times higher; furthermore, there are significant fluctuations down the profile and even within single layers. Radioactive anomalies and the presence of yellow uranyl vanadates in covered calcrete and sabkha horizons is most probably related to calcrete and playa uranium mineralization (Dahlkamp, 1993 and Noble et al., 2011).

The present study aims to study the petrography and mineralogy of the playa surfacial deposits bearing radioactivity to reveal the uranium minerals and distributions of uranium in the various playa types.

\section{GEOLOGIC BACKGROUND}

Generally, most of the south Western Desert of Egypt is a cuesta type landscape of Late Jurassic to Cretaceaus clastics, of small to medium high escarpments with extensive sand, sand dunes and gravel sheets situated between them. In some places of relatively minor extension, Precambrian basement rocks are exposed (Fig.1). Precambrian rocks cover an area of some $40,000 \mathrm{~km}^{2}$ in south Western Desert of Egypt. The majority of these basement rocks are exposed around Gebel Uweinat-Gebel Kamil area at the convergence of the frontiers of Libya, Egypt and Sudan. Smaller basement exposures like Bir Safsaf-Nusab El Balgum studied area, Gebel El Asr and Gebel Um Shaghir complexes are exposed between Bir Safsaf and Aswan city (Klizsch and Schandelmeier, 1990). Uplifting of these basement rocks in south Western Desert of Egypt, which known as "Gebel Uweinat-Bir 


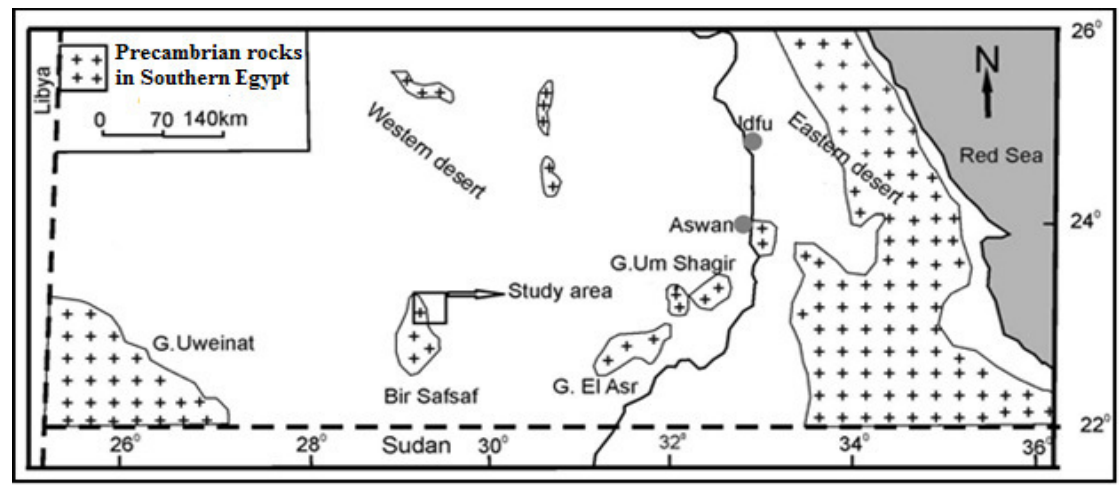

Fig. 1: Location map of the studied area showing the Precambrian basement rocks in the Southern Egypt

Safsaf-Aswan uplift system", is related to continental transcurrent faults which continue to the fracure zones in the Atlantic Ocean (Schandelmeier and Pudlo, 1990).

The study area (Fig. 2) is covered by basement and sedimentary rocks that are chronologically arranged from oldest to youngest following Conoco (1987); Azzaz et al. (1994) and Assran et al. (2014) as follow: Gneisses and migmatites, older grey granites, younger red granites, Mesozoic sandstones (Six hills and Abu Ballas formations), post tectonic Nusab El Balgum volcanic complex, that injected with subvolcanic granitic dykes,
andQuaternary sediments. The Quaternary sediments are represented by surficial playa deposits as well as sand dunes and sheets.

The geologic rock unites bearing radioactivity in the studied area are younger red granites, Nusab El Balgum volcanic mass and Mesozoic sandstones showing highest radiometric field and lab measurements up to 75 , 150 and 120ppm uranium content, respectively (Soliman, et al., 1984; Abdel Warith, 1997 and Assran, et al., 2014).

The surficial playa deposits in the studied area are covering large area of about $30 \mathrm{~km}$ long and 2 to $4 \mathrm{~km}$ width, as individual sepa-

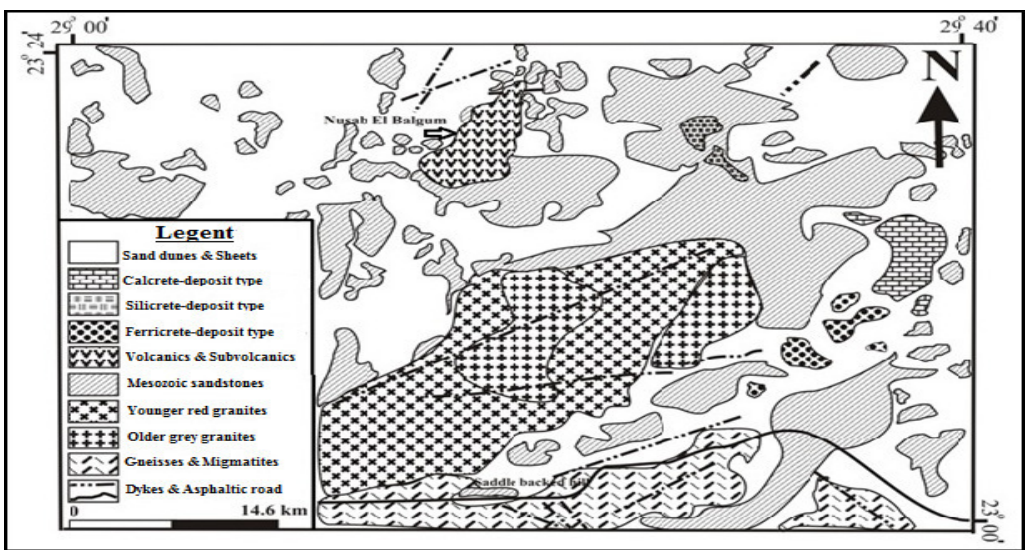

Fig. 2: Geological map of the studied area, Modified after Conoco, 1987; Azzaz et al., 1994 and Assran et al., 2014. 
rated outcrops along the eastern part of study area (Fig. 2). It can be classified into three types: First type of the largest area is outcropping as separated areas of dark yellow colour (Figs. 3 and 4). Each area covers at least $3 \mathrm{~m} \times 8 \mathrm{~m}$ with thickness reaching $0.5 \mathrm{~m}$ from wadi level (Fig. 3), but all the separated areas collectivly cover $20 \mathrm{~km}^{2}(10 \times 2 \mathrm{~km})$. It is composed of slightly ferruginated siltstones with carbonate minerals (calcite and/or gypsum) as cement (Fig. 4), as well as filling the thin fractures of somewhat consolidated ferruginous siltstone nodules with diameter reaching $5 \mathrm{~cm}$. These types of playa deposits can represent a calcrete deposit type of carbonate minerals as cement (IAEA, 1990).

Along the southern extension of the calcrete deposit type (Fig. 2) is outcropping the

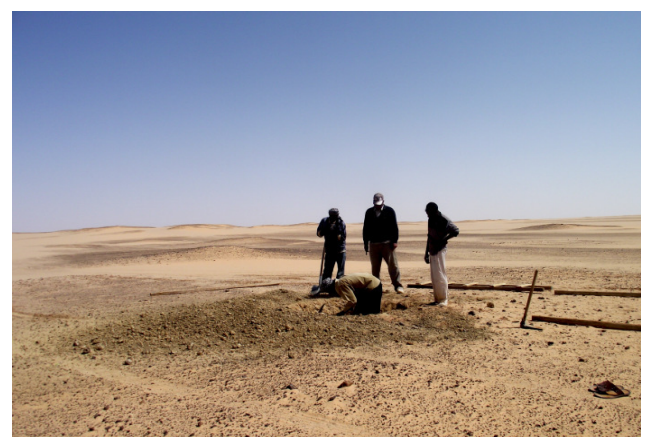

Fig. 3 : Photograph showing small open-pit in calcrete deposit type (observe scattered and slightly elevated dark patches in the view, which represent calcrete deposits)

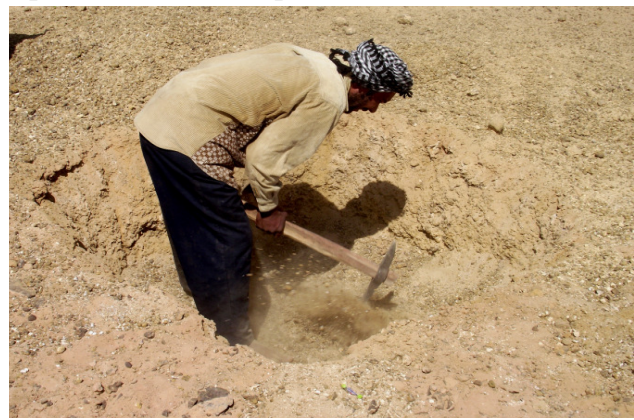

Fig. 4: Close up view shows open-pit in calcrete deposit type with carbonate minerals of white color second type of surficial deposit type as separated piles or conical-shaped forms (Figs. 5 and 6). It is composed of ferruginated pebbly siltstones and covers large separated areas. Each area of them covers at least $100 \mathrm{~m}$ $\mathrm{x} 100 \mathrm{~m}$ and settled in obvious depressions of slightly slopping. These deposit type is the ferricrete type, cemented by ferric oxides (IAEA, 1990). Obvious rock fragments of slightly massive nature as consolidated reworked ferruginated pebbly siltstones are present.

The third type of surficial deposits occurs as small separated outcrops along the northeastern part of the mapped area (Fig. 2). Each small outcrop is measuring about $20 \mathrm{~m}$ x $20 \mathrm{~m}$, as duricrust or hard silicified pebbly sandstone bed of thickness about 20 to $30 \mathrm{~cm}$

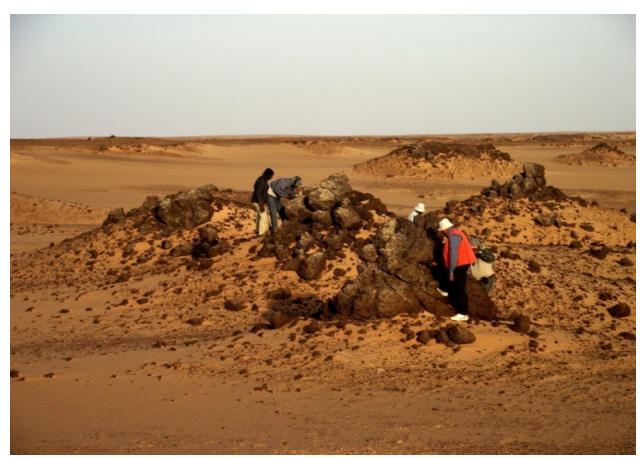

Fig. 5:Photograph showing remnants of ferricrete deposits as conical-shaped piles in shallow depression

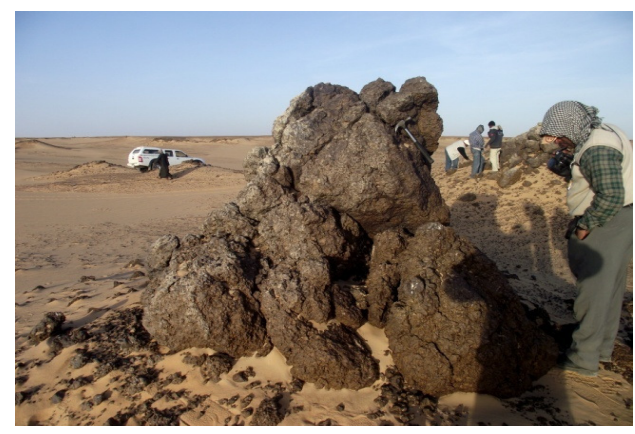

Fig. 6: Close up view shows single conicalshaped pile of ferricrete deposit type 
(Figs. 7\&8). This type of surficial deposits can represent the silicrete deposit type of silica cement (IAEA, 1990).

\section{RADIOMETRIC MEASURMENTS}

The field radiometric measurements of $\mathrm{U}$ and $\mathrm{Th}$ are obtained using a $\gamma$-ray spectrometer instrument (model RS-230 BGO Super-Spec, from Radiation Solution Inc, Canada). Radiometric measurements of the first calcrete deposit type are ranging from 25 to $19 \mathrm{ppm}(\mathrm{eU})$ in the surface sediments. Four small open-pits with depth about $0.5 \mathrm{~m}$ located in different sites of these deposits have been done, because it covered by sand sheets (Figs. $3 \& 4)$, and four samples were collected. The field radiometric measurements of the second type of these deposits (ferricrete) are ranging from 41 to $23 \mathrm{ppm}(\mathrm{eU})$ on the surface. The radiometric measurements of the third type

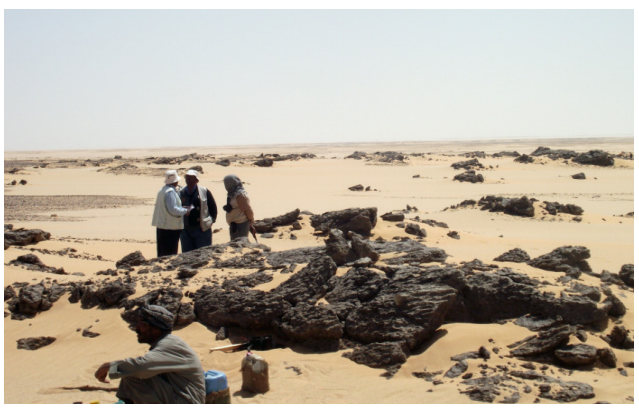

Fig. 7: Photograph showing silicrete deposit type as small scattered outcrops of hard silicified pebbly sandstone thin bed reaches $30 \mathrm{~cm}$ thickness

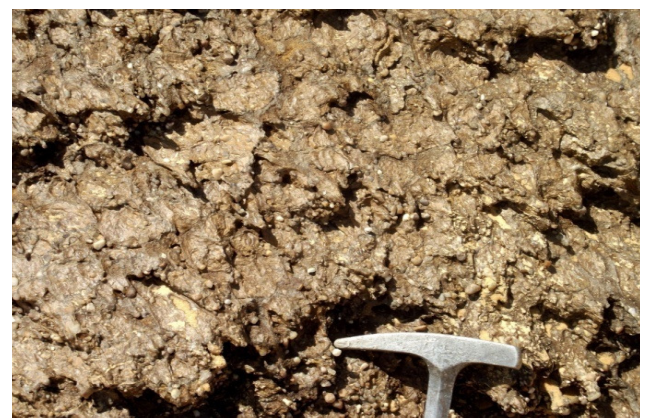

Fig. 8: Close up view shows silicified pebbly sandstone bed of silicrete deposit type (silicrete) in the field are ranging from 35 to $34 \mathrm{ppm}(\mathrm{eU})$ on the surface.Also, eleven samples of highest radiometric measurements in the field for different calcrete, ferricrete and silicrete playa deposit types are analyzed chemically to measure $\mathrm{U}$ and Th ppm contents (Table 1).

\section{PETROGRAPHY AND MINERALOGY}

Microscopically, only ten thin sections of silicrete- and ferricrete-deposit types were prepared due to its massive nature than the calcrete-deposit type of friable nature and enriched with powdered carbonate materials. Detailed studies of these thin sections using binocular polarizing microscope revealed the following:

Silicrete deposits are mainly composed of subangular to subrounded fine quartz, silt and clay grains, where they were deposited by rapid deposition from the source rocks under arid conditions. The subangular to subrounded peripheries of these grains suggest different distance of transportation. The matrix represents $>15 \%$ of the sediments occurring as amorphous silica and clay (Figs.9 \& 10). Few crystals of xenotime (Fig. 9) and zircon (Fig. 10) which are responsible for radioactivity of such deposits are observed. Zircon occasionally zoned observed as long crystals

Table 1: Field measurements of eU, eTh and chemical measurements for $\mathrm{U}$ and $\mathrm{Th}$ as well as their ratios for selective samples of silicrete-, calcrete- and ferricrete-deposit types

\begin{tabular}{|c|c|c|c|c|c|c|c|c|c|}
\hline \multirow[b]{2}{*}{$\begin{array}{l}\text { Deposit } \\
\text { type }\end{array}$} & \multirow[b]{2}{*}{$\begin{array}{c}\text { Sample } \\
\mathrm{N}_{0} .\end{array}$} & \multicolumn{4}{|c|}{ Measurements in the field } & \multicolumn{4}{|c|}{ Measurements in the lab. } \\
\hline & & $\begin{array}{r}\mathrm{eU} \\
(\mathrm{ppm})\end{array}$ & $\begin{array}{r}\text { eTh } \\
(\mathrm{ppm})\end{array}$ & eU/eTh & $\mathrm{Th} / \mathrm{eU}$ & $\begin{array}{r}\mathrm{U} \\
(\mathrm{ppm})\end{array}$ & $\begin{array}{r}\mathrm{Th} \\
(\mathrm{ppm})\end{array}$ & $\mathrm{U} / \mathrm{Th}$ & $\mathrm{Th} / \mathrm{u}$ \\
\hline \multirow{2}{*}{ Silicrete } & 1 & 34 & 7 & 4.86 & 0.21 & 74 & 53 & 1.40 & 0.72 \\
\hline & 2 & 35 & 7 & 5.00 & 0.20 & 100 & 88 & 1.14 & 0.88 \\
\hline \multirow{4}{*}{ Calcrete } & 3 & 24 & 9 & 2.67 & 0.38 & $140^{\circ}$ & 13.3 & 10.53 & 0.10 \\
\hline & 4 & 25 & 13 & 1.92 & 0.52 & 180 & 18.8 & 9.57 & 0.10 \\
\hline & 5 & 19 & 8 & 2.38 & 0.42 & 130 & 15.5 & 8.39 & 0.12 \\
\hline & 6 & 19 & 8 & 2.38 & 0.42 & 190 & 10 & 19.00 & 0.05 \\
\hline \multirow{5}{*}{ Ferricrete } & 7 & 28 & $\ddot{4}$ & 7.00 & 0.14 & $110^{\circ}$ & 54 & 2.04 & 0.49 \\
\hline & 8 & 23 & 4 & 5.75 & 0.17 & 136 & 92 & 1.48 & 0.68 \\
\hline & 9 & 35 & 10 & 3.50 & 0.29 & 142 & 48 & 2.96 & 0.34 \\
\hline & 10 & 36 & 6 & 6.00 & 0.17 & 115 & 40 & 2.88 & 0.35 \\
\hline & 11 & 41 & 2 & 20.50 & 0.05 & 106 & 56 & 1.89 & 0.53 \\
\hline
\end{tabular}




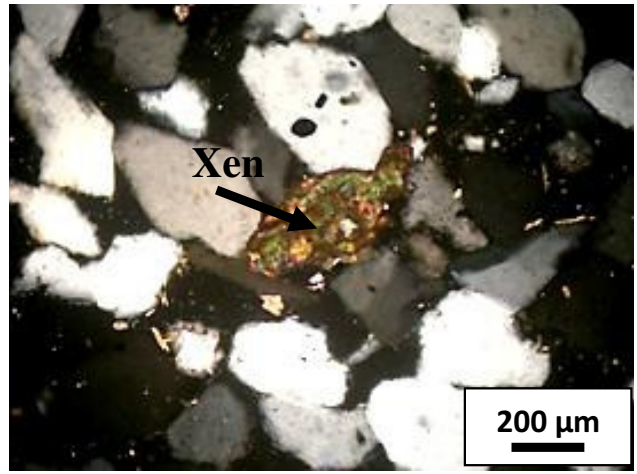

Fig. 9: Photomicrograph of silicrete showing well-formed crystal of xenotime,XPL

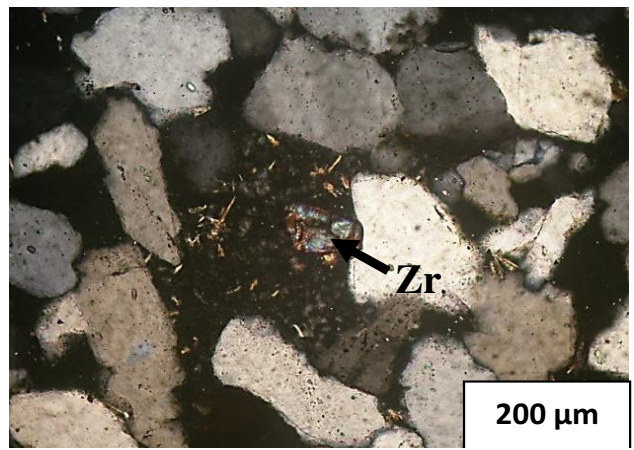

Fig. 10: Photomicrograph of silicrete showing zircon embedded in the matrix,XPL

embedded in the matrix or included in quartz grains may suggest different sources.

Ferricrete deposits are characterized by dominant iron oxides $(<40 \%$ of the sediments), cementing subangular to subrounded grains of quartz, silt and clay $(>60 \%)$. Rare crystals of zircon are observed (Fig. 11). The radioactive material may be distributed in several ways mainly; accumulated by adsorbing onto the surface of iron oxides as uranyl complexes (Fig. 12), disseminated in iron oxides cement (Fig. 13) and occasionallyfilling the micro-fractures within the iron oxides cement (Fig. 14).

\section{MINERALOGICAL STUDY}

For mineralogical study, each sample of higher radiometric measurement in the field

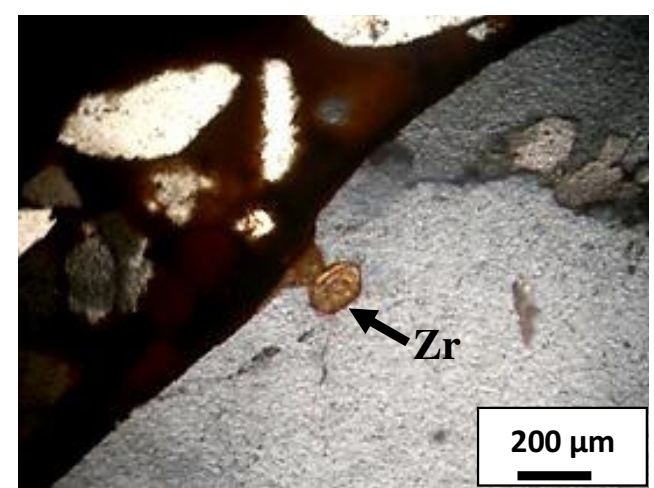

Fig. 11: Photomicrograph of ferricrete showing zoned zircon crystal in quartz,XPL

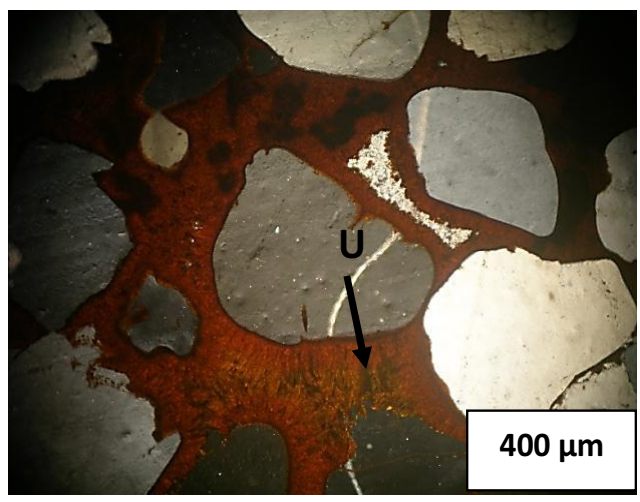

Fig. 12: Photomicrograph of ferricrete showing radioactive materials adsorbed onto iron oxides cement, XPL

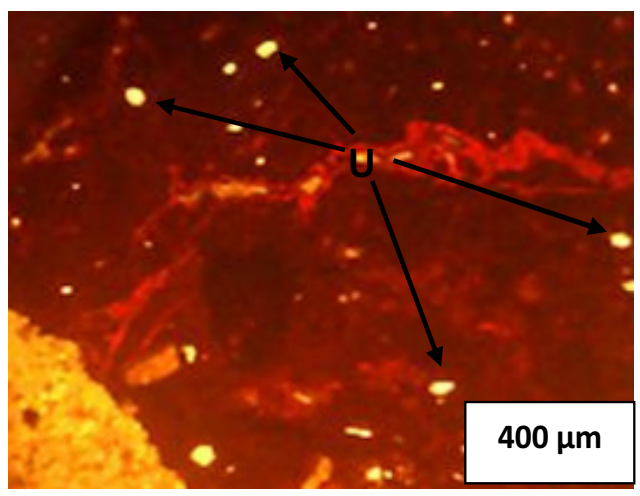

Fig. 13: Photomicrograph of ferricrete showing radioactive materials disseminated in iron oxides cement ,PPL 


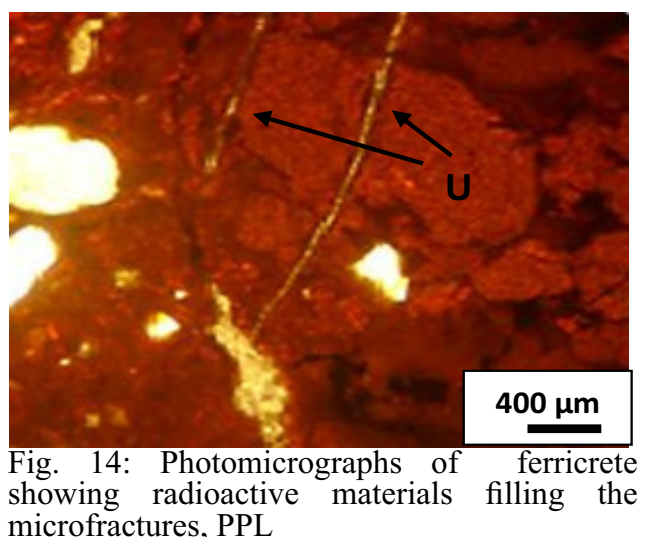

was subjected to mineralogical study to identify radioactive minerals responsible for the high radioactivity. Each sample was crushed and then sieved into various $\mathrm{mm}$ sizes. The $0.53 \mathrm{~mm}$ to $0.063 \mathrm{~mm}$ fractions were concentrated using Wilfley table to remove the light minerals as quartz and feldspars. The heavy fractions were then dried. Magnetite was separated by hand magnet, then the magnetic free fractions were separated by bromoform (SP.G $=2.82)$. This was followed at the same time by hand picking under the binocular microscope, where bright yellow secondary uranium coatings occurs on the grains (Fig. 15) and invisible in hand specimen. Each mineral sample was pulverized to 200 mesh size for XRD analysis. The result of this examination indicated occurrence of kaolin and quartz minerals in the XRD pattern (Fig. 15), but secondary uranium minerals are not detected, due to its occurrence in amorphous state as iron oxides.

Due to the presence of secondary radioactive minerals adsorbed in amorphous state as thin staining on sand, silt and clay grains and invisible by the naked eye, so it is difficult to peel little amount of the radioactive minerals from the aforementioned grains to conduct the heating process and analysis by XRD. For this reason, EDX analysis was applied to identify the secondary radioactive minerals. Carnotite $\left[\mathrm{K}_{2}\left(\mathrm{UO}_{2}\right)_{2}\left(\mathrm{VO}_{4}\right)_{2} \cdot 3 \mathrm{H}_{2} \mathrm{O}\right]$ mineral was detected (Fig. 16), by Quanta FEG 250 EDX Genesis in Central Metallurgy Research and Development institute, Cairo, Egypt.

\section{GEOCHEMISTRY AND RADIOACTIVITY}

Field radiometric measurements of $\mathrm{e} \mathrm{U}$ and eTh of silicrete-, calcrete- and ferricrete-deposit types were obtained using a $\gamma$-ray spectrometer instrument; model RS-230 BGO Super-Spec, Canadian type. Also, the contents of $U$ and $T h$ in the selected 11 samples of high radioactivity were chemically measured by Arsenazo III (extraction method for uranium and precipitation method for thorium, Marczanko, 1986), through the spectrophotometer colorimetric technique (Table 1), as

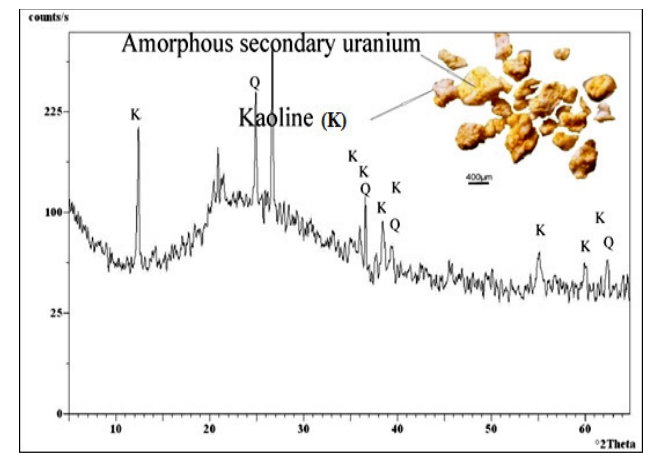

Fig. 15: XRD pattern of Kaolinite (K) and quartz (Q) as well as photomicrograph of amorphous secondary uranium coatings undetected by XRD technique

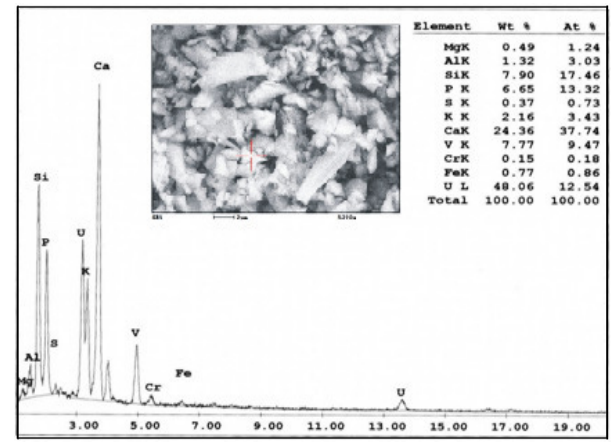

Fig. 16: ESEM image and its spectrum of radioactive carnotite mineral 
well as trace elements of the same selected samples are chemically analyzed (Table 2 ) in the laboratories of Nuclear Materials Authority.

The data mentioned in Table (1) are rep-

Table 2: Trace elements analysis for selective samples of silicrete-, calcrete- and ferricretedeposit types

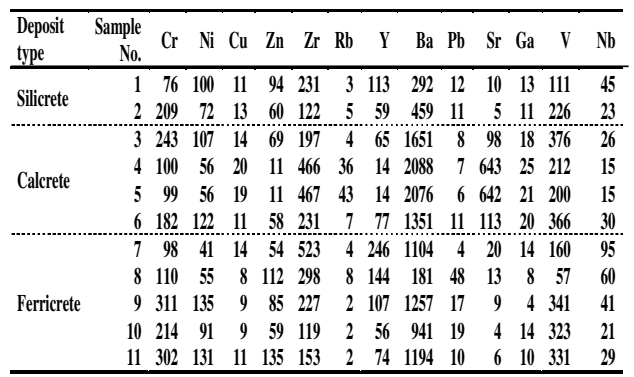

resented graphically as bar diagrams (Figs. 17-20) to compare between the uranium and thorium contents of these deposit recognized in the field and those measured chemically. On contrast with the field measurements (eU and eTh ppm) and the chemical analysis data show a higher U content (190-74ppm) and Th content (92-10ppm) (Figs. 17\&18). Also, eU/eTh and U/Th ratios of all samples $>1$, suggesting $U$ enrichment in the studied samples (Figs. 19\&20). This contradiction between radioactivity measured in both field and lab can be explained due to recent $U$ addition (the daughters which emit gamma-ray are not produced yet or at least, the decay series did not reach the equilibrium state). Relation between uranium and thorium is helpful to test if there is enrichment or depletion of these elements. Plotting U versusTh (Fig.21) show that all the analyzed samples plotted under the line $\mathrm{Th} / \mathrm{U}=1$ (after Wenrich, 1984) indicating uranium enrichment in all samples.

The equation eU-(eTh/3.5) reflects the uranium mobilization. If the result of this equation equals zero, it indicates that no uranium mobilization took place (i.e. fresh sam-

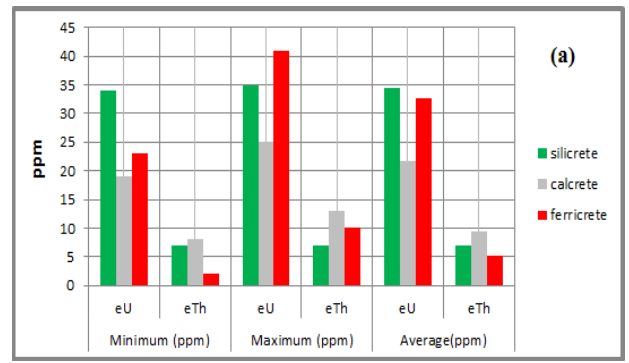

Fig. 17: Bar diagram shows the minimum, maximum and average of eU and eTh (field measurements) of the playa deposit types encountered in the study area

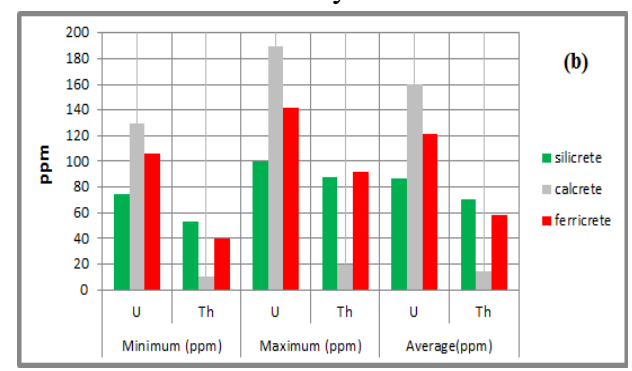

Fig. 18: Bar diagram shows the minimum, maximum and average of $U$ and Th (chemical analysis)

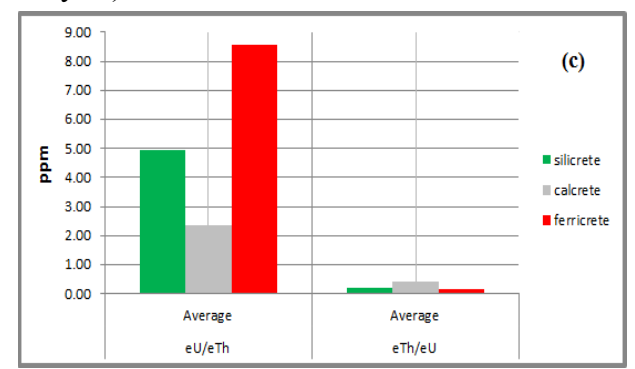

Fig. 19: Bar diagram shows average eU/eTh and $\mathrm{eTh} / \mathrm{eU}$ ratios

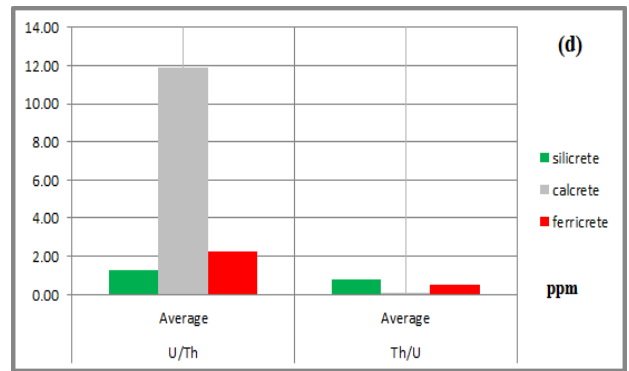

Fig. 20: Bar diagram shows average U/Th and $\mathrm{Th} / \mathrm{U}$ ratios 


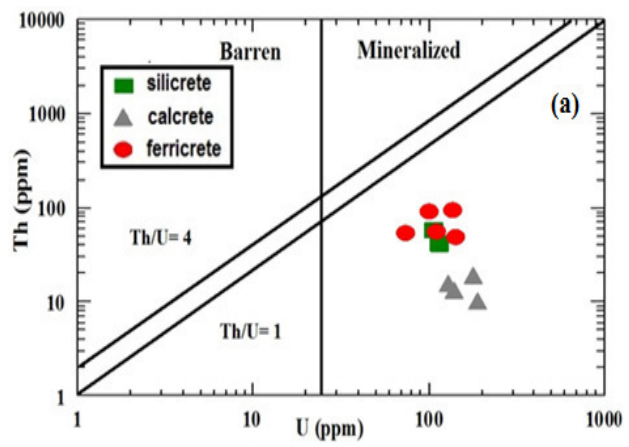

Fig. 21: $U$ versus $\mathrm{Th}$, the mineralized and barren fields after Wenrich (1984)

ples). When it is greater than zero, it means that uranium was enriched (added to rock), while the negative values mean uranium leached out. On the mobility diagram (Fig. 22); all plotted samples show eU-(eTh/3.5) values above zero reach up to 40 , indicating uranium enrichment. Also, the mobility diagram (Fig. 23) shows U-(Th/3.5) values above zero and sometimes reaches up to 200 . The high permeability of playa allowing uranium impregnation and may adsorb uranium from its bearing solution and/or the prevalence of oxidation conditions and complexing ions, that cause precipitation of uranium as complex uranyl ions (Cuney, 2003).

Plotting of trace elements ( $\mathrm{Zr}$, $\mathrm{Y}$ and $\mathrm{Rb}$ ) versus $U$ on binary diagrams (Figs. 24-26), revealed that all the analyzed samples lie on mineralized field of Wrenich (1984), which is consistent with detected minerals as zircon and xenotime. High values of these elements ( $\mathrm{Zr}, \mathrm{Y}$ and $\mathrm{Rb}$ ) can be attributed to the immobility of these elements in the surficial environment, due to high chemical and mechanical stabilities of their host minerals against chemical decomposition weathering. Hence, these minerals tend to be highly concentrated as grains among other heavy minerals near the primary source rocks. This fact is confirmed with the results obtained from petrographic study.

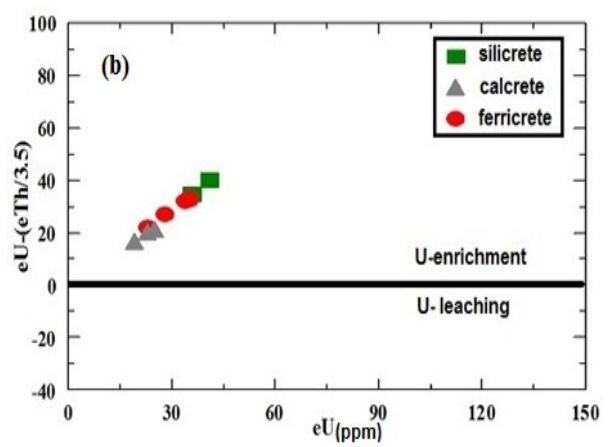

Fig. 22: Uranium mobilization equation eU(eTh/3.5) versus eU

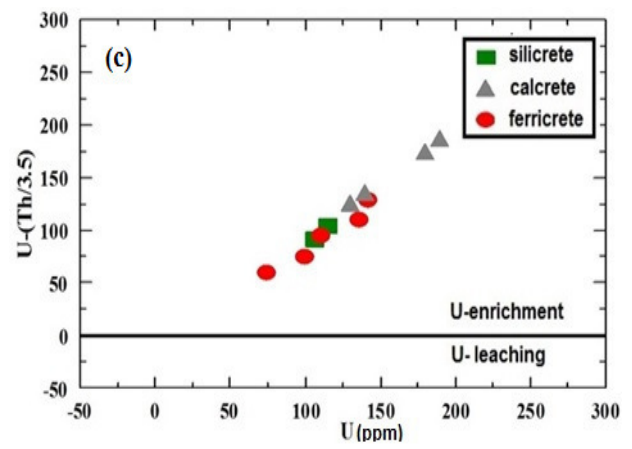

Fig. 23: Uranium mobilization equation U-(Th/ 3.5) versus $U$

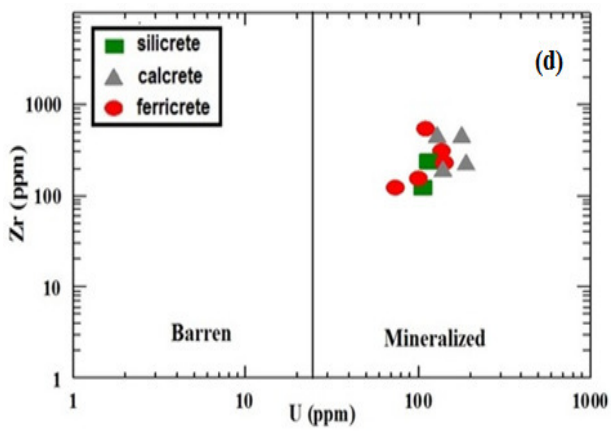

Fig. 24: U versus Zr after Wenrich (1984) 


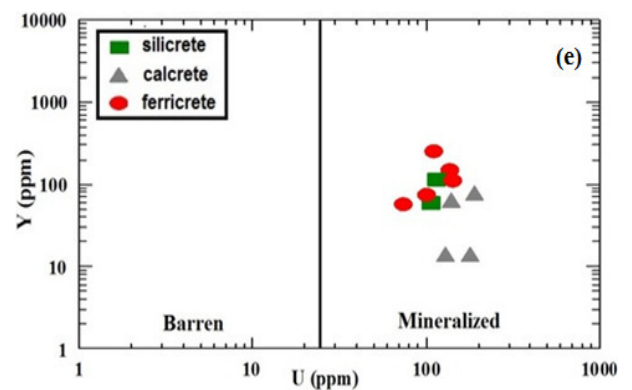

Fig. 25 : U versus Y after Wenrich (1984)

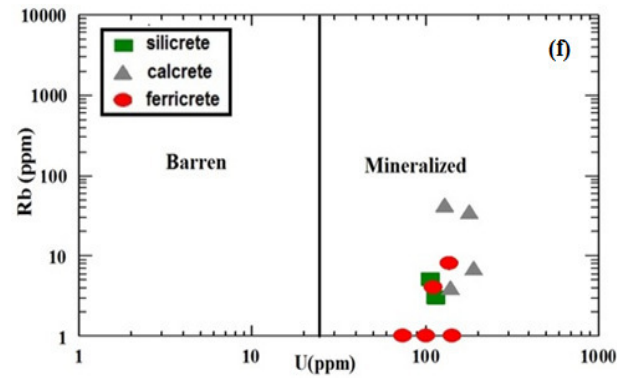

Fig. 26 : U versus Rb after Wenrich (1984)

\section{CONCLUSION}

The physiography and climate of south Western Desert of Egypt along with the geological setting make it an excellent target area for exploration of uranium-surficial (playa) deposits. Where, the playa deposit (silicrete, calcrete and ferricrete) encountered in the present studied area are showing high radiometric measurements in both field and lab. Due to the availability of suitable conditions; such as dry weather, shallow depth of groundwater and uranium source rocks as younger granites and volcanic rocks of Nusab El Balgum mass, this led to the formation of such deposits.

Petrographic, mineralogical and chemical studies confirmed enrichment of the studied collected samples representing the different playa deposit (silicrete, calcrete and ferricrete) by secondary uranium minerals. Carnotite mineral identified by EDX technique and represent the main secondary uranium mineral, as well as accessory minerals as zircon and xenotime are relatively of high radioactivity of these deposition. The studied playa deposits are considered to be favorable environment for uranium deposits, where all samples show eU/eTh and U/Th average ratios greater than unity reaches up to 20 and 19 respectively, by application of Gamma spectrometry technique and chemical analysis.

Accordingly, the author expect much higher uranium contents at deeper levels in the playa deposits, especially calcrete-deposit of thickness and covers large areas, than those measured in samples collected from shallow depths of about $0.5 \mathrm{~m}$. So that, such deposits need deeper trenches to determine the thickness and uranium potentiality of these deposits. In this case, the playa deposits in the studied area can be considered as an excellent target for exploration and easy uranium extraction, due to its presence as loose surficialdeposits covering extensive area and uranium content reaching up to $190 \mathrm{ppm}$ by chemical analysis.

\section{REFERENCES}

Abdel Warith, M.A.,1997. Mineralogical, Petrographical and Geochemical Studies of the Radioactive Occurrences in the Volcanic Rocks, Nusab El Balgum Area, South Western Desert, Egypt. M.Sc. Thesis, Fac. Sci., Cairo Univ., $178 \mathrm{p}$.

Assran, H.M.; Dardir, A.M.; Abdel Ghani, I.M.; Hamed, A.A.; Arbab, A.A.; El Sawey, E.H.E.; El Sherif, A.M.; Abu Zeid, E.K.; Ahmed, A.A.; Moghazy, N.M.; Abu Elatta, S.A., and Abdelrahman, M.E.H., 2014. Uranium prospecting in Bir Safsaf-Atmur El Kibeish-Nusab El Balgum area, south Western Desert, Egypt. Scientific Internal Report, NMA, Cairo, Egypt, 98p.

Azzaz, S.A.; Soliman, M.M.; Sabet, A.H.; ElTokhy, M., and El Baroudy, A.F., 1994. Pan African Basement of Bir Safsaf area East Sahran African Craton. Qatar Univ. Sci. J., 14 (1), 172-183. 
Boyle, D.R.,1984. The genesis of surficial uranium deposits. In: Surficial Uranium Deposits. Report of the working Group on Uranium Geology, IAEA-TECDOC 322, 45-52.

Briot, P., and Fuchs, Y., 1984. Processus de mineralization uranifere des calcretes: Unehypothese non pedologique. In: Surficial Uranium Deposits. Report of the Working Group on Uranium Geology, IAEA-TECDOC 322, 1524.

Britannica Online Encyclopedia, 2012. Playa (geology). http://www.britannica.com/print/topic/ 464368 .

Butt, C.R.M., 1988. Major uranium provinces: Yilgran Block and Gascoyne Province, Western Australia, in Recognition of Uranium Provinces, IAEA, 272-304.

Carlisle, D.,1984. Surficial uranium occurrences in relation to climate and physical setting. In: Surficial Uranium Deposits.Report of the working Group on Uranium Geology, IAEATECDOC 322, 25-35.

Conoco-Corporation, LTD, 1987. Geological Map of south Western Desert Egypt. Scale 1:500.000, sheet No NF 53 NV, Gilf Kabeir Plateau.

Culbert, R.R.; Boyle, D.R., and Levinson, A.A.,1984. Surficial uranium deposits in Canada. In: Surficial Uranium Deposits.Report of the working Group on Uranium Geology, IAEA-TECDOC 322, 179-191.

Cuney, M., 2003. Mechanisms of U-Fractionation. U solubility controls in silicate melts and fluid phase, partial melting and fractional crystallization. IAEA short course.

Dahlkamp, F.J.,1993. Uranium ore deposits, Springer-Verlag, Heidelberg, 460p.

International Atomic Energy Agency, (IAEA), 1990. Uranium in the environment. 1993 Training program on uranium in the environment, Regina Univ., Canada.,198p.

Klitzsch, E., and Schandelmeir, H., 1990. The geology of Egypt (Said,R., Ed.) Blkema/Rotterdam/Brookfield.

Marczanko, Z.,1986. Separation and spectrophotometric determination of elements. Halsted press: a division of John Willy and sons New York, 677p.

Mckay, A., and Miezitis, Y.,2001. Australia's uranium resources, geology and development of deposits, AGSO-Geoscience Australia Resource, Report 1.

Noble, R.R.P.; Gray, D.J., and Ried, N.,2011. Regional exploration for channel and playa uranium deposits in Western Australia using groundwater. Appl. Geochemistry, 26, 19561974.

Otton, J. K., 1984. Surficial uranium deposits: summary and conclusions. In :Surficial Uranium Deposits. Report of the Working Group on Uranium Geology, IAEA-TECDOC 322, 243-247.

Pagel, M.,1984. Petrology, mineralogy and geochemistry of surficial uranium deposits. In: Surficial Uranium Deposits. Report of the Working Group on Uranium Geology, IAEATECDOC 322, 37-44.

Salman, A.B.; El Aassy, I.E., and Rakaiby, M.L., 1984. Contribution to radioactivity of South Western Desert, Egypt. Ann. Geol. Surv. Egypt, 14, 43-57.

Schandelmeir, H., and Pudlo, D.,1990. The Central-Africa fault zone in Sudan-a possible continental transform fault. Berliner Geowiss. Abh., 120-A, 31-44.

Simonsen, H.A.; Boydell, D.W., and James, H.E., 1980. The impact of new technology on the economics of uranium production from low-grade ores. $5^{\text {th }}$ Int. Symposium of the Uranium Institute, 87.

Wenrich, K.J., 1984. Mineralization of breccia pipes in northern Arizona [abs.], in Bogdanov, N.A., ed., Special session of the International 'Lithosphere' Programme: Inter. Geol. Congress, $27^{\text {th }}, 9,380-381$. 


\title{
تسجيل أولى لرواسب البلايا السطحيه الحامله لليورانيوم في جنوب شرق منطقة نصاب

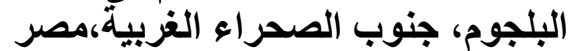

\author{
حسن محمد عسران
}

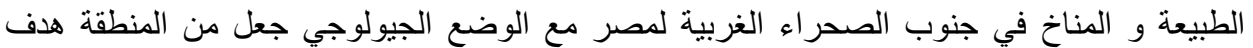

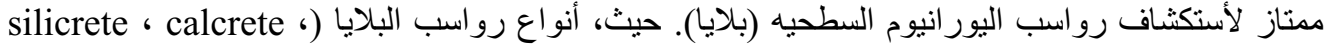

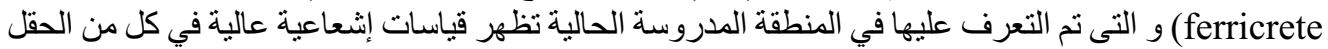

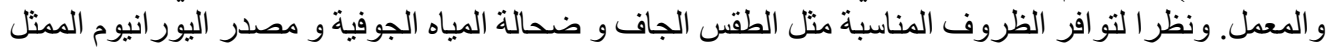

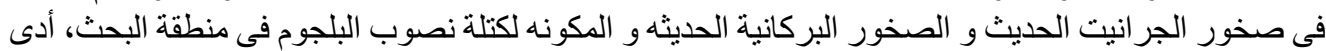
ذلك إلى تكوين مثل هذه الرواسب.

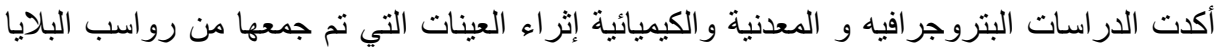

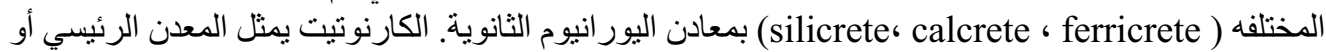

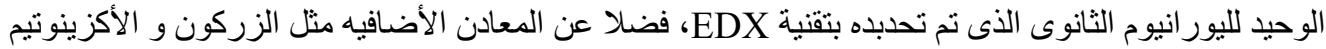

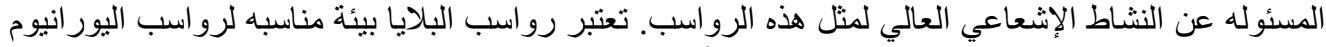

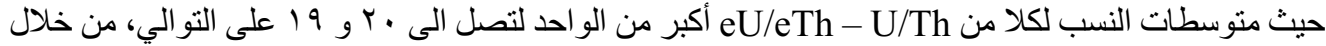
تطبيق تقنية مطياف جاما و التحليل الكيميائي. وفقا لذللك، المؤلف يتوقع زيادة محتويات اليور انيوم أعلى بكثير عند مستويات أكثر عمقا في رواسب البلايا،

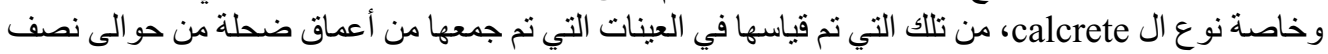

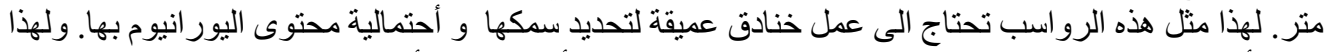

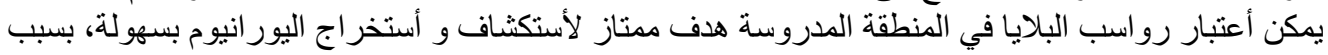

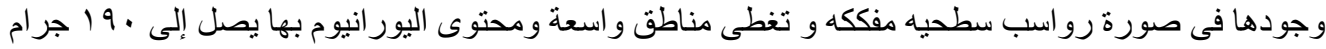
فى الطن (ppm) عن طريق التحليل الكيميائي. 